\title{
Twenty Years After: Scientific Research in the Field of Knowledge Organization in Romania (1993-2012) ${ }^{1}$
}

\author{
Victoria Frâncu \\ Tabita Popescu \\ National Library of Romania
}

"Carol I" Central University Library of Bucharest

\begin{abstract}
Purpose/thesis: : The main point that we want to emphasize in this study is that research in the field of knowledge organization in Romania over the last twenty years is unequally distributed among different professional categories ranging from library and information science faculty members, library professionals, software tools developers to independent researchers. The specific situation of library and information science functioning as a university department in Romania with an interruption of 20 years (1970-1990) affected the overall situation of scientific research in the specific fields associated with this discipline.

Approach/methods: The study covers three stages: data collection, data recording and data interpretation. Results and conclusion: The primary outcomes of the scientific research activities in question are publications (books, book chapters and journal articles). Given this, our interest will be directed towards the analysis to what extent research and publications have made an impact on the evolution of Romanian libraries over this twenty years span.
\end{abstract}

\section{Keywords}

Knowledge Organization. Romania. Literature review.

Received: 15.10.2014. Revised: 11.12.2014. Accepted: 23.06.2015.

\section{Introduction}

Traditionally, theoretical investigations are carried out at universities and research centers, while applied research in such fields like library and information science (LIS) is mostly conducted in libraries and information centers. The twenty-year break in LIS education at Romanian universities (1970-1990) had direct negative impact on research activities in this field, particularly in the first years after it was restarted. Most if not all the faculty were recruited from among librarians with modest scientific work experience, lacking the necessary pedagogical skills and with little theoretical knowledge, as they were rather

1 The article is a revised version of the paper presented on the 13th International ISKO Conference (Cracow, 2014) and published in its proceedings (Knowledge Organization in the 21st Century: Between Historical Patterns and Future Prospects. Ed. by W. Babik. Wurzburg 2014, 556-563). 
professional librarians ${ }^{2}$. This situation, combined with the students' lack of interest with university career has become even worse because of the lack of initiatives in promoting qualitative selection criteria for the staff recruitment at the LIS department at the universities. This resulted, as we shall see later in this paper, in unfavorable conditions for research activities in general. The applied research, however, was better carried out in libraries and related institutions and by individual researchers interested in libraries and particularly in the field of Knowledge Organization (KO). Nevertheless, the absence of high level scientific research, of long and medium term research programs in universities led to an unsystematic and often low-rated scientific research in the Romanian LIS.

\section{Objectives}

The rationale of this study is to show who conducts scientific research in KO field in Romania and to what extent this research affects the evolution of Romanian libraries. This is a longitudinal study observing the evolution of a number of variables over 20 years, between 1993 and 2012. It is also a descriptive-interpretative study since it describes the status of $\mathrm{KO}$ research without manipulating it and finally, it is a retrospective study that looks back in time in order to discover trends or patterns in the Romanian KO research.

\section{Definitions of the terms, scope and limitations of the study}

In 2008, The Knowledge Organization journal, the ISKO (International Society of Knowledge Organization) official journal, dedicated its special issue to the conceptual boundaries of the concept of knowledge organization, aiming "to explore the definition of the interdisciplinary field of knowledge organization through historical and contemporary perspectives" (McIlwaine, Mitchell, 2008, 79).

Initially, KO was associated with activities specific to library and information science (document description, indexing and classification). However, the meaning of KO was and still is, reconsidered to encompass more activities, such as: the nature and quality of knowledge organizing processes, knowledge organizing systems used to organize documents, document representations, works and concepts (Hjørland, 2008). An indicative study on $\mathrm{KO}$ research in keeping with Hjørland's coverage of the field was presented at the Spanish ISKO conference in 2003 (López-Huertas, Jiménez Contreras, 2004).

The implementation of knowledge organization system (KOS) and, in particular, its search interface is of tremendous importance considering its search and retrieval performances. Interoperability and integration of different information languages either structured or not, included into a semantic network say much about the effectiveness of KOS. Gnoli (2008, 144) also states that "communication between indexers, reference librarians, computer

2 The Library and Information Science Department of the Faculty of Letters at the University of Bucharest was re-founded at the initiative of Prof. Ion Stoica, at that time also Director of "Carol I" Central University Library of Bucharest. He became head of department and organized it the best he could, given the circumstances. 
scientists and information architects" is crucial in designing systems that respond appropriately to the challenges of today.

A comprehensive definition of KOS is given by Hodge (2000):

The term knowledge organization systems is intended to encompass all types of schemes for organizing information and promoting knowledge management. Knowledge organization systems include classification and categorization schemes that organize materials at a general level, subject headings that provide more detailed access and authority files that control variant versions of key information such as geographic names and personal names. Knowledge organization systems also include highly structured vocabularies, such as thesauri, and less traditional schemes, such as semantic networks and ontologies.

KO has different meanings. For the purpose of this study we include: library catalogues, descriptive cataloguing, classification, classification systems, indexing, indexing languages, thesauri and thesaurus building, authority files, terminology issues, information search and retrieval, semantic networks, open access to information resources, integrated library systems, computer science applied to libraries, innovative solutions for library systems development.

In order to meet our objectives we investigated not only the literature in the field of $\mathrm{KO}$, but also other activities like: editing journals, organizing scientific events, participating in national and international scientific events and educational programs, reporting work done at scientific forums, participating in working groups for creating and developing language tools for $\mathrm{KO}$, developing software tools for $\mathrm{KO}$ research.

The data were collected from both printed and electronic resources. The data collection methods differed and were appropriate to the type of available resources. Questionnaires and interviews, content analysis, citation analysis and historical source analysis were also applied. The most convenient data collection method, though not that extensively applied, was the descriptor-based search in electronic resources (e.g. international bibliographic and full-text databases, institutional repositories).

The content analysis was conducted on the collected data in order to illustrate the research work done over the last 20 years. The document types include but are not restricted to: books and book chapters, doctoral dissertations, papers presented at national and international forums, studies and research reports presented at national and local meetings, articles published in specialized $\mathrm{KO}$ and library journals.

\section{Methodology of the study}

Our fundamental concern in approaching this study was to employ a research methodology able to provide us with essential information to help formulating pertinent conclusions on the issues of KO research topics in Romania. From the very beginning it was obvious that, given the circumstances explained earlier, it would be difficult to obtain data that are accurate and reasonable enough so that they can be recorded and then quantified. We derived the selection criteria from the definition of the field. In the next subsections we present detailed procedures applied in data collecting, organizing the material coherently, and then making systematic observations based on them. 


\subsection{Data collection}

Collecting the relevant data was rather strenuous. As noted above, this study was the first of its kind, therefore most of the information collected was unstructured and spread throughout a variety of resources. We mention here the most frequently used data collection methods. Written communication proved to be very effective data collection technique and was particularly useful in the case of research activities that were not necessarily materialized in written form, i.e. published materials. Individual interview was another approach that provided, apart from the needed data, additional information on the scientific community and detailed accounts on the research conditions for a particular scientific activity discussed. The content analysis of the literature in Romanian LIS journals was the method which provided most of the data recorded in our database. The content analysis of historical sources was also a valuable method providing literature from the KO literature list available at http://www.isko.org/lit.html.

\subsection{Data recording}

The collected data were recorded in a database that enabled us to discover patterns in the Romanian $\mathrm{KO}$ research. We generated reports showing the distribution of the variables. We used seven variables mainly qualitative and nominal, except for the time variable which is a quantitative one.

- Variable 1: author, was used to find out the ratio between the total number of works and the number of the most productive authors.

- Variable 2: profession with three attributes: faculty, librarians and others (i.e. software tool developers and independent researchers).

- Variable 3: type of work, with four attributes namely: research report - bringing up new knowledge, well-grounded arguments, new viewpoints, application of known elements in new conditions; professional work - explanatory, instructive, based on already known information, using scientific approach and language and suggesting its practical application; descriptive work - providing elaborate presentation of the latest knowledge and concepts in the field; informative work - which merely presents already known information giving no personal views or interpretation.

- Variable 4: type of manifestation, with five attributes: book, book chapter, doctoral thesis, journal article, conference paper.

- Variable 5: descriptors, with 28 attributes, showing in a differentiating way the coverage of $\mathrm{KO}$ subjects in Romania.

- Variable 6: year of publication, with 20 attributes i.e. the 1993-2012 span.

- Variable 7: language of publication with four attributes - Romanian, English, French and Hungarian.

\subsection{Data interpretation}

First of all, it must be said that it was hard to obtain the exhaustiveness of the study under the circumstances described earlier, given the heterogeneous nature of data sources. The database built for our purposes was accompanied by successive Excel import and export actions in order to generate tables and graphs. 
The results of our research present the authors and the professional categories they belong to. Out of the 70 authors identified, only four published more than 10 works. There are authors whose output is high enough to denote a real preoccupation with KO subjects, as shown in table 1 . Yet, more than half of the authors wrote only one article which means that publishing is somehow secondary or even accidental for them. Another notable aspect is that 28 works were written in collaboration, which means more demanding standards for each of the co-authors and hence, added value of their work.

Table 1. Authors and their publications

\begin{tabular}{|l|c|c|c|}
\hline \multicolumn{1}{|c|}{ Surname, Name } & Books & Articles & Total \\
\hline Frâncu, Victoria & 4 & 30 & 34 \\
\hline Niculescu, Zenobia & 7 & 14 & 21 \\
\hline Repanovici, Angela & 3 & 9 & 12 \\
\hline Dumitrăsconiu, Constanța & 4 & 7 & 11 \\
\hline Curta, Olimpia & 4 & 3 & 7 \\
\hline Matei, Dan & 0 & 7 & 7 \\
\hline Costea, Gabriela & 0 & 5 & 5 \\
\hline Ostafe, Doina & 0 & 5 & 5 \\
\hline Balan, Dorina & 0 & 5 & 5 \\
\hline Gurka-Balla, Ilona & 2 & 2 & 4 \\
\hline Andrian, Alexandru C. & 1 & 2 & 3 \\
\hline Boruna, Adriana & 1 & 2 & 3 \\
\hline Moraru, Violeta & 0 & 3 & 3 \\
\hline Chihaia, Lăcrămioara & 0 & 2 & 2 \\
\hline Dragoi, Elena & 0 & 2 & 2 \\
\hline Dragota, Ioana & 0 & 2 & 2 \\
\hline Lazar, Monica & 0 & 2 & 2 \\
\hline Man, Raluca & 1 & 1 & 2 \\
\hline Musat, Rodica & 0 & 2 & 2 \\
\hline Podocea, Ion & 0 & 2 & 2 \\
\hline Robu, Ioana & 0 & 2 & 2 \\
\hline Coravu, Robert & 1 & 2 & 2 \\
\hline Gruia, Luminita & 0 & 47 \\
\hline Authors with 1 work and works in collaboration & \\
\hline
\end{tabular}

The ratio between the number of works and their authors is rather unequal, so that almost half of publications (78, i.e. about $46 \%$ ) were written by four authors, who have written between 11 and 34 works each, while the rest (92, i.e. about 54\%) are authored by 49 people (Fig. 1). At the same time, out of the four leading authors only one belongs 
to faculty and astonishingly, produced no genuine research work in the studied period of time (Tab. 2).

Table 2. The output of authors by number of works

\begin{tabular}{|c|c|c|}
\hline No. of works & No. of authors by no. of works & Percentage \\
\hline 78 & 4 authors: 11-34 works / author & $46 \%$ \\
\hline 42 & 9 authors: 3-7 works / author & $25 \%$ \\
\hline 20 & 10 authors: 2 works / author & $12 \%$ \\
\hline 30 & 30 authors: 1 work / author & $17 \%$ \\
\hline Total 170 & & $100 \%$ \\
\hline
\end{tabular}

These results show on one hand, a deficit in the research activity of Romanian LIS faculty and, on the other hand, that LIS students in Romania have little if any chance for research-oriented education. This situation has a critical impact on the library field in the long run.

Figure 1. The output of the most productive authors

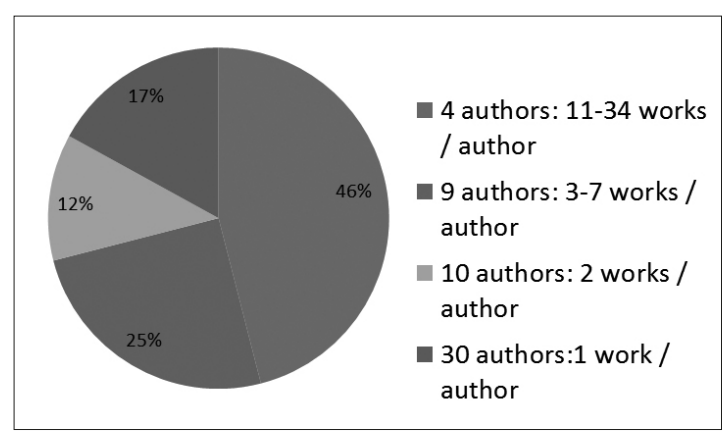

The extremely important to our study was the investigation of the professional categories of authors. Figure 2 demonstrates that librarians represent the category most concerned with $\mathrm{KO}$ issues in Romania in the last 20 years. The faculty represent only $17 \%$ of the authors included in our study.

Figure 2. Professional categories of authors

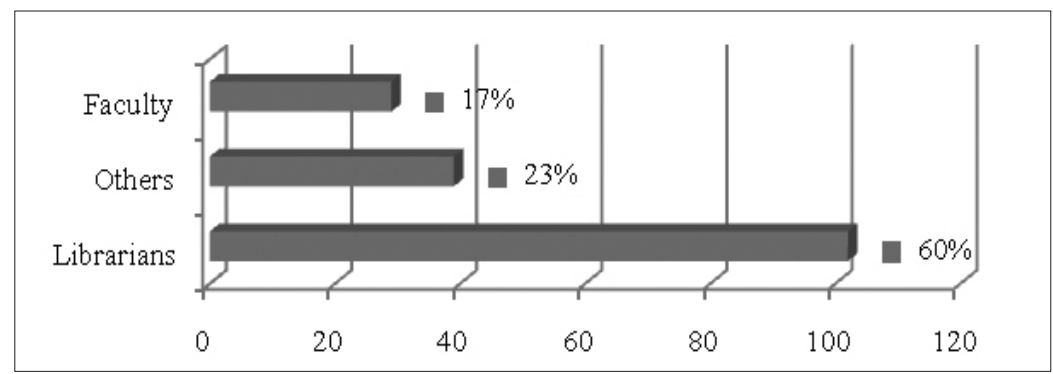


The next variable - type of the work, is related to the previous one and it also gives surprising results. Genuine research work is conducted rather by librarians and other professional categories than by the faculty (Fig. 3). The research reports eight doctoral theses, where six of them were written by librarians.

Figure 3. Type of works included in the study

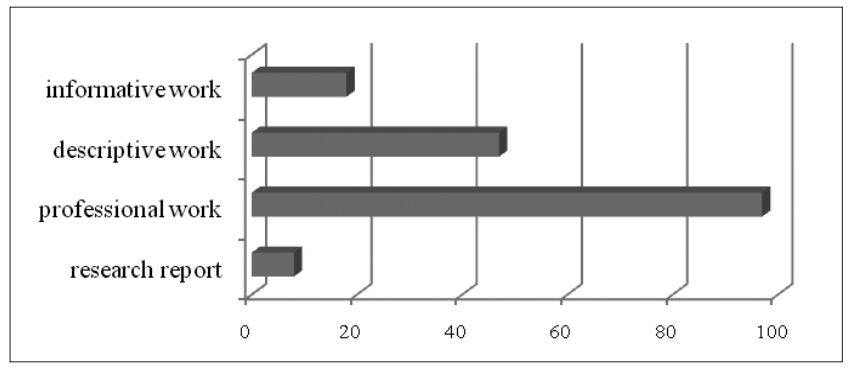

The high percentage of professional works (57\%) shows the authors approach to problems in $\mathrm{KO}$ domain. On the other hand, we found research reports which represent only $5 \%$ of the total set of publications.

In recent years in the Romanian library community we observe an evident decline of interest in updating or adjusting the knowledge taught at universities in many LIS disciplines in general, let alone in $\mathrm{KO}$ in particular. Figure 4 shows the distribution of topics represented by keywords. This will help us draw a real image of the relationship between topics and professions.

Figure 4. Distribution of subjects of publications

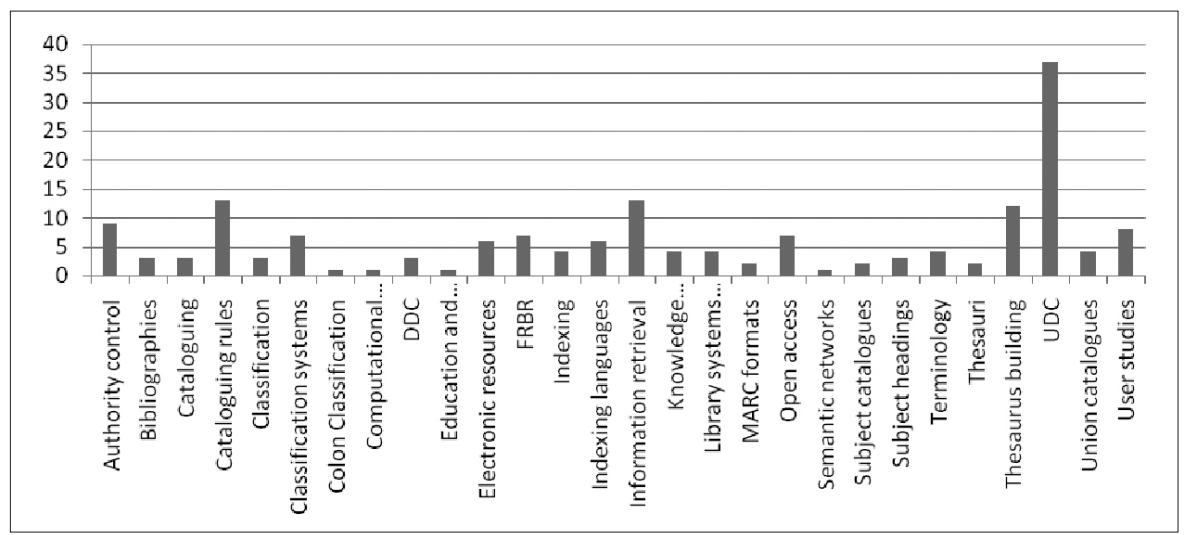

The most frequent subject was and still is related to the Universal Decimal Classification (UDC). This has always been treated with great interest in Romanian $\mathrm{KO}$ community and quite often even controversial, calling into question whether it is still worth using it or not. Issues of thesauri and their construction, cataloguing rules and information retrieval are well represented in subjects distribution. Likewise, authority control, other classification 
systems, Functional Requirements for Bibliographic Records (FRBR) model, open access and user studies hold an important place among the topics of Romanian $\mathrm{KO}$ literature, particularly in 2009-2012.

Table 3. Sequence of topics not treated by academics

\begin{tabular}{|l|l|l|l|l|l|}
\hline Authority control & 9 & Library systems development & 2 & Terminology & 1 \\
\hline Electronic resources & 4 & Open access & 1 & Thesauri & 2 \\
\hline FRBR & 7 & Semantic networks & 1 & Thesaurus construction & 1 \\
\hline Indexing & 4 & Subject catalogues & 1 & Union catalogues & 2 \\
\hline Knowledge management & 3 & Subject headings & 3 & User studies & 1 \\
\hline
\end{tabular}

The distribution of topics and professional categories leads to interesting results. Table 3 lists issues, although highly relevant for the present coverage of $\mathrm{KO}$ field, not raised by academics in their publications. All the mentioned subjects were matter of interest to librarians and other professional categories.

In terms of type of manifestation, journal articles are the most frequent form of expression of viewpoints and opinions in $\mathrm{KO}$ domain (Fig. 5).

Figure 5. Distribution of types of manifestation

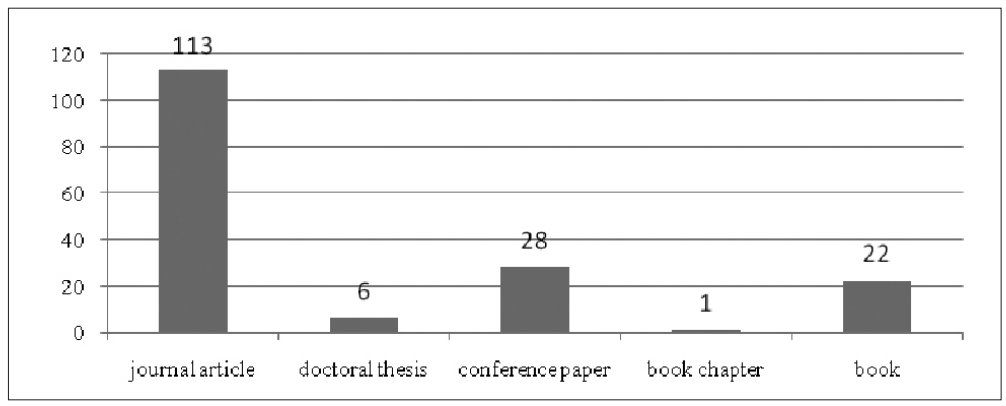

The language variable shows, as expected, the prevalence of Romanian as language of publication. Out of the 170 works included in the database, 135 are in Romanian, 28 in English and 2 in Hungarian. We also identified two works in Romanian, English and French and three in Romanian and English. Although foreign language works represent only $20 \%$ of the total output, the trend is ascending.

The last variable taken into account was the chronological aspect. The longitudinal study covering KO research activities carried out in Romania over the last 20 years proved that research interests have lower or higher rates according to the importance of a certain $\mathrm{KO}$ issue at a given moment. Figure 6 shows an abrupt rise in the production in 1995, followed by double values in 1996-1997. It was the time when librarians were searching for alternative tools for subject description than library classification exclusively. Another key moment was between 2006 and 2007 when there was a growing interest in authority files and efforts were made to introduce a common indexing language. In recent years there 
were ups and downs in the scientific production though the level stayed high, recording the highest one in 2011. Major topics in the last four years include: open access, electronic resources, user studies, semantic web.

Figure 6. Chronological aspects of KO research work in Romania (number of publication per year)

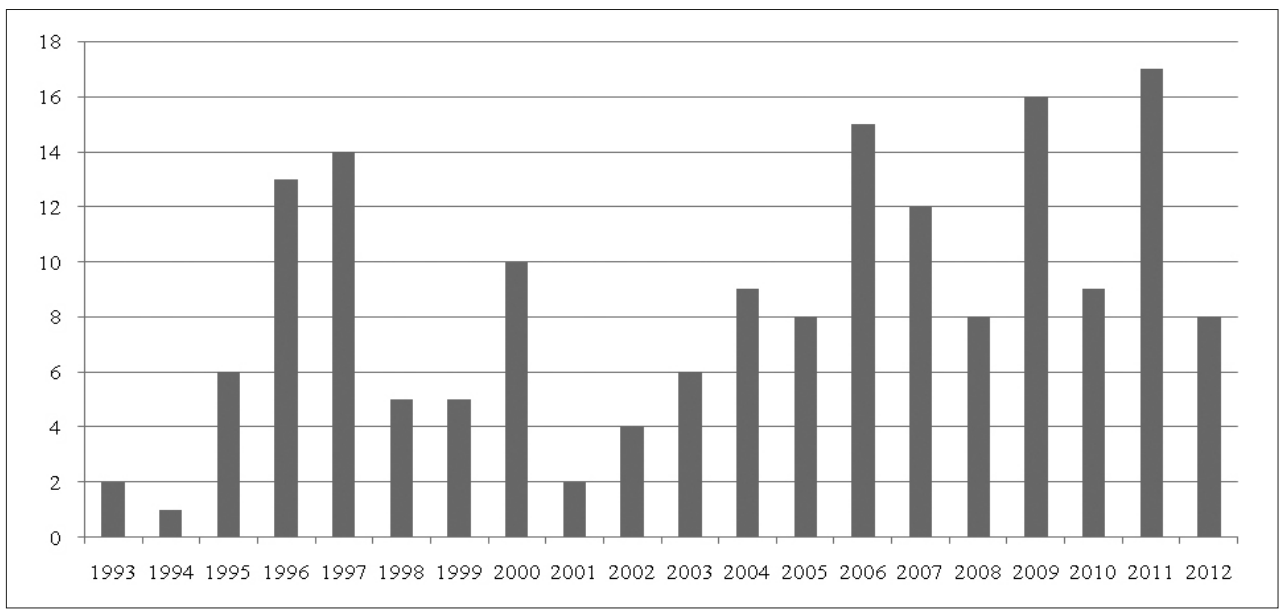

\section{Conclusion}

The topics studied and presented here as research results had a huge impact on evolution of libraries in Romania. Such topics being, after all, determined by the library community needs on one hand and by the international developments in $\mathrm{KO}$ field on the other hand. With the introduction of computers in libraries, content description by the means of UDC became insufficient and improving subject access by natural language was necessary. There was a growing awareness for building thesauri based on the UDC and moreover, those thesauri went multilingual. Establishing and maintenance of authority files was a starting point for authority control on bibliographic records. Subject indexing, as major concern for improved information retrieval, imposed the need to adopt a unique indexing language. The French RAMEAU was translated into Romanian and currently it is being validated and soon will be declared as national indexing language. The creation of a national information portal Romanian Library Network Science \& Technology - ROLiNeST (http://rolinest.edu. ro) marked the beginning of a Romanian union catalogue. Semantic networks, organization of electronic resources, open access, better library services resulting from user studies are other facets of $\mathrm{KO}$ research applied in libraries.

Computer scientists and information architects have been working for innovative solutions for libraries. There are good examples of Romanian made library systems, eBibliophil and TinREAD. Both have integrated thesaurus where each descriptors are accompanied by appropriate UDC codes. 
And since the subject of this study is Romanian $\mathrm{KO}$ research, we suggest some solutions for improving the research environment such as: motivating and encouraging diligent students to make a career in education, teaching fundamentals of research at the university, reconsidering the benefits a good research climate at institutional level.

\title{
References
}

Gnoli, C. (2008). Ten long-term research questions in Knowledge Organization. Knowledge Organization, 35(2/3), 137-149.

Hjørland, B. (2008). What is Knowledge Organization (KO)? Knowledge Organization, 35(2/3), 86-101. Hodge, G. (2000). Systems of Knowledge Organization for digital libraries: Beyond traditional authority files. [online] Washington, DC: The Council on Library and Information Resources. [08.11.2014], http://www.clir.org/pubs/reports/pub91/contents.html

López-Huertas, M. J.; Jiménez Contreras, E. (2004). Spanish research in Knowledge Organization (1992-2001). Knowledge Organization, 31(3), 136-150.

McIlwaine, I. C.; Mitchell, J. S. (2008). Preface to Special Issue "What is Knowledge Organization". Knowledge Organization, 35(2/3), 79-81.

\section{Dwadzieścia lat później: badania w zakresie organizacji wiedzy w Rumunii (1993-2012)}

\begin{abstract}
Abstrakt
Cel/teza: Podstawowa teza postawiona podczas prowadzonych badań dotyczy nierównomiernego reprezentowania badań prowadzonych w obszarze organizacji wiedzy w Rumunii w ciągu ostatnich dwudziestu lat wśród środowisk zawodowych pracowników akademickich z ośrodków kształcenia w zakresie bibliotekoznawstwa i informacji naukowej, bibliotekarzy, programistów oraz niezależnych badaczy. Charakterystyczna sytuacja, w której znalazła się dziedzina informacji naukowej i bibliotekoznawstwa w Rumunii a szczególnie dwudziestoletnia przerwa w aktywności (1970-1990) miała znamienny wpływ na aktywność naukową badaczy w ramach tej i pokrewnych dyscyplin naukowych. Koncepcja/metody badań: Prezentowane badania zostały przeprowadzone w trzech etapach: zbieranie danych, utworzenie bazy danych, analiza i interpretacja zgromadzonych danych.

Wyniki i wnioski: Podstawowe wnioski płynące z przeprowadzonych badań odnoszą się do konkretnych rodzajów aktywności naukowej (książki, rozdziały w książkach, artykuły w czasopismach). Szczególna uwaga zostanie poświęcona analizie wpływu publikacji naukowych na rozwój bibliotek w Rumunii w ciągu ostatnich dwudziestu lat.
\end{abstract}

\section{Słowa kluczowe}

Organizacja wiedzy. Rumunia. Przegląd piśmiennictwa.

Dr VICTORIA FRANCU has a long experience as a librarian at "Carol I" Central University Library of Bucharest. Her professional knowledge was acquired through individual and institutional training and moved from general to very specific. She graduated with a Master of Arts degree from the University of Bucharest - Faculty of Letters, Romanian-English Department, and continued with library science in-depth study as she became Ph.D. in Library and Information Science at the University of Antwerp (Belgium) with the thesis "Multilingual Access to Information using an Intermediate Language". Her research interests cover but are not limited to cataloguing and subject indexing, indexing languages, classification, thesauri. Since 
1995 she has participated in professional meetings both in Romania and abroad and published papers in monographs and conference proceedings. Victoria Frâncu has been a member of the International Society for Knowledge Organization (ISKO) since 1996. In 2007 she became a member of the Universal Decimal Classification Consortium (UDCC) Advisory Board. She has been teaching Theories and Techniques of Cataloguing and Indexing as well as a course on Classification Systems at the Department of Library and Information Science of the Bucharest University.

Dr TABITA POPESCU graduated from the Polytechnic Institute of Bucharest, a prestigious school where she experienced the importance of science-based research. After that she decided to work in library, first in "Carol I" Central University Library of Bucharest and then in National Library of Romania. Having interest in this field she continued her academic studies in project management, cultural management and strategy. Her satisfaction with the management tasks is definitely associated with the RAMEAU project in Romania, i.e. the creation of a Romanian universal thesaurus based on French RAMEAU - an indexing tool that could be used by all libraries within the Romanian library network. Currently she is Head of the Research and Development Department of the National Library of Romania, approaching the final stage of her doctoral study at the Faculty of Letters at the University of Bucharest. Her dissertation is entitled "Library and information science research in Romania after 1990: a critical analysis". Her areas of interest in the professional field include knowledge organization and library management. 